\title{
Digital transformation of business processes in aic: starting conditions and priorities
}

\author{
S.A. Novoselova*, and G.A. Solodovnikova \\ Saratov State Agrarian University named after N.I. Vavilov, 410012, 1, Theatre sq., Saratov, \\ Russian Federation
}

\begin{abstract}
The article examines the starting conditions for digital transformation in agriculture in Russia, identifies the main stages in the history of the development of agricultural production. The author studied the regulatory documents on digital transformation, the components of the Central Information and Analytical System of State Information Support for Agriculture, analyzed the current state of the use of complex digital agricultural solutions by agricultural producers. It also assesses the achieved target indicators of the departmental project «Digital Agriculture», identifies trends in their change over the period. Drivers for the development of digital transformation of the agro-industrial complex in Russia have been formed and presented.
\end{abstract}

\section{Introduction}

Currently, digitalization is a priority area for the development of agriculture in Russia, since, starting in 2019, the Ministry of Agriculture of the Russian Federation has begun to implement the sectoral program «Digital Agriculture» [1].

Digital transformation is the process of integrating digital technologies into all aspects of business activities, requiring fundamental changes in technology, culture, operations and the principles of creating new products and services. Thus, digital transformation is not only investment in new technologies (artificial intelligence, blockchain, data analysis and the Internet of Things), but also a deep transformation of products and services, organization structure, development strategy, customer relations and corporate culture.

The history of the development of agricultural production can be represented as a chain of «mechanization» - «automation» - «informatization» - «digitalization» - «robotization» «artificial intelligence» - «smart agriculture».

The main trajectories of digital transformation in agriculture are as follows:

- at the national level: functioning of digital platforms of the Ministry of Agriculture of Russia, predictive analytics based on big data, with tools of a distributed ledger, artificial intelligence;

- at the regional level: smart sectoral planning, smart contracts;

- at the agribusiness level: mass implementation of complex digital agro-solutions, mass acquisition of digital competencies by specialists of agricultural enterprises.

* Corresponding author: nsanovoselova@yandex.ru 


\section{Methods}

During the study, the following regulatory documents were studied:

- Decree of the President of the Russian Federation No. 204 of May 7, 2018 «On national goals and strategic objectives of the development of the Russian Federation for the period up to 2024» [2];

- The program «Digital Economy of the Russian Federation» (Order of the Government of the Russian Federation dated July 28, 2017 No. 1632-R) [3].

The main conclusions of the study were based on a statistical analysis of official data from the Ministry of Agriculture of the Russian Federation, as well as data from a survey of agricultural organizations in the Saratov region on the use of existing and implementation of new complex digital agricultural solutions.

\section{Results}

The process of digitalization of agriculture at the level of collection and accumulation of information can be represented in the form of a diagram (Figure 1).

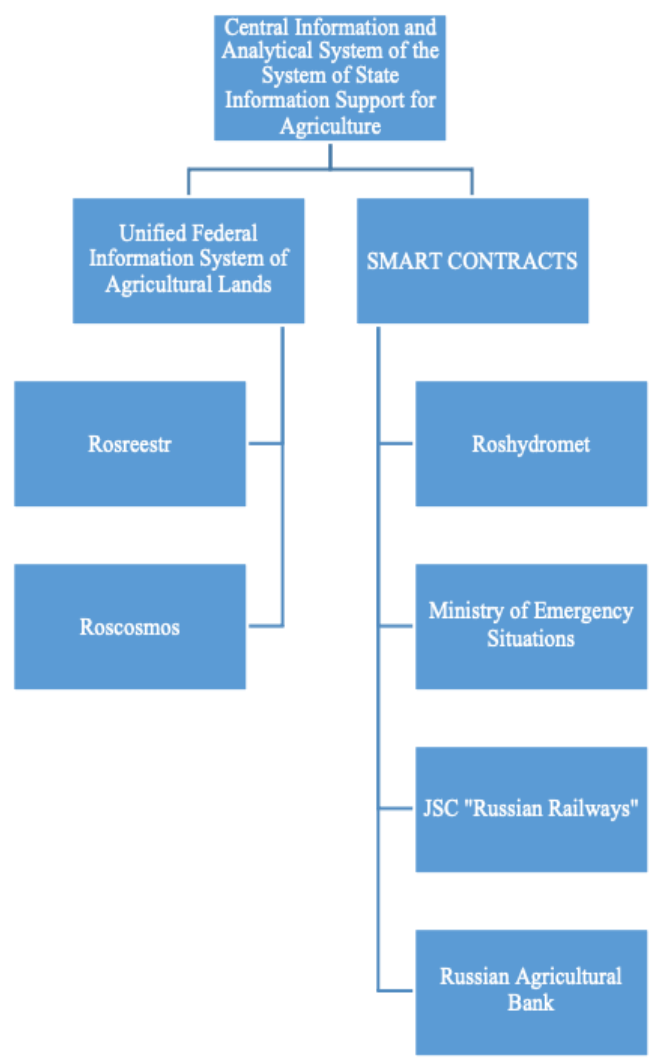

Fig.1. Main components Central Information and Analytical System of the System of State Information Support for Agriculture.

The analysis showed that the use of certain elements of digital agriculture is taking place at a rapid pace, especially in those areas where scientifically grounded systems for supporting agrobioprocesses already existed and operated (Table 1). In particular, precision 
farming systems, systems for accounting and assessing land use, systems for assessing technosphere factors, accounting and management systems.

Table 1. The share of individual elements of digital agriculture in the regional systems of the domestic agro-industrial complex.

\begin{tabular}{|l|c|c|c|}
\hline \multirow{2}{*}{\multicolumn{1}{|c|}{ Elements of digital agriculture }} & \multicolumn{3}{c|}{$\begin{array}{c}\text { \% coverage of regional } \\
\text { agricultural systems }\end{array}$} \\
\cline { 2 - 4 } & $\mathbf{2 0 1 8}$ & $\mathbf{2 0 1 9}$ & $\mathbf{2 0 2 0}$ \\
\hline Using precision farming systems & 42 & 53 & 60 \\
\hline $\begin{array}{l}\text { Application of technologies for deep processing of } \\
\text { agricultural raw materials }\end{array}$ & 38 & 50 & 58 \\
\hline Using smart farm technologies & 27 & 35 & 47 \\
\hline System of digitized land contours & 60 & 80 & 100 \\
\hline $\begin{array}{l}\text { Use of information systems for assessing agricultural } \\
\text { production factors }\end{array}$ & 55 & 75 & 97 \\
\hline $\begin{array}{l}\text { Use of remote sensing data systems and unmanned } \\
\text { aerial vehicles }\end{array}$ & 40 & 52 & 86 \\
\hline Use of advanced accounting systems (CRM, ERP) & 32 & 54 & 78 \\
\hline Use of cloud information technology & 25 & 38 & 74 \\
\hline Use of programs for processing Big Data & 16 & 34 & 57 \\
\hline
\end{tabular}

The low percentage of coverage of regional systems of the agro-industrial complex on deep processing of products (58\%) and the use of programs for processing Big Data $(57 \%)$ is associated with high costs, in the first case, the purchase and acquisition of equipment, in the second case, with a shortage of specialists in Big Data.

Despite such starting positions in the field of digitalization of agriculture, tasks were set to achieve the following targets within the framework of the Digital Agriculture project (Table 2)

Table 2. Targets of the departmental project «Digital Agriculture» [1].

\begin{tabular}{|l|c|c|c|c|c|c|}
\hline \multicolumn{1}{|c|}{ Targets } & $\mathbf{2 0 1 9}$ & $\mathbf{2 0 2 0}$ & $\mathbf{2 0 2 1}$ & $\mathbf{2 0 2 2}$ & $\mathbf{2 0 2 3}$ & $\mathbf{2 0 2 4}$ \\
\hline $\begin{array}{l}\text { Share of resources in Big } \\
\text { Data (\%): }\end{array}$ & & & & & & \\
\hline $\begin{array}{l}\text { agricultural land destination } \\
\text { (from the total area } \\
\text { agricultural land) }\end{array}$ & 50 & 75 & 90 & 100 & 100 & 100 \\
\hline $\begin{array}{l}\text { working and productive } \\
\text { livestock (of the total }\end{array}$ & 25 & 35 & 50 & 75 & 90 & 100 \\
\hline
\end{tabular}




\begin{tabular}{|l|l|l|l|l|l|l|}
\hline livestock this category) & & & & & & \\
\hline $\begin{array}{l}\text { agricultural machinery (of } \\
\text { the total number of units) }\end{array}$ & 45 & 60 & 75 & 90 & 100 & 100 \\
\hline $\begin{array}{l}\text { Share of SMART contracts } \\
\text { with recipients of } \\
\text { subsidies, \% }\end{array}$ & 5 & 25 & 50 & 75 & 100 & 100 \\
\hline $\begin{array}{l}\text { The share of material costs } \\
\text { (fuels and lubricants, } \\
\text { fertilizers, electricity, } \\
\text { planting material, feed, etc.) } \\
\text { in the cost of agricultural } \\
\text { products, } \%\end{array}$ & 60 & 55 & 50 & 47 & 45 & 43 \\
\hline $\begin{array}{l}\text { Labor productivity growth, } \\
\text { abre of investments in }\end{array}$ & 105 & 125 & 150 & 175 & 190 & 200 \\
\hline $\begin{array}{l}\text { Share } \\
\text { Digital Technologies } \\
\text { (including for the purchase } \\
\text { and implementation of digital } \\
\text { products and technologies of } \\
\text { domestic production), } \%\end{array}$ & $1(0,5)$ & $3(1,5)$ & $7(5)$ & $10(7)$ & $15(10)$ & $25(20)$ \\
\hline $\begin{array}{l}\text { The share of specialists of } \\
\text { agricultural enterprises who } \\
\text { have undergone retraining } \\
\text { and have competencies in the } \\
\text { field of the digital economy } \\
\text { to work with digital products } \\
\text { and technologies, } \%\end{array}$ & 10 & 15 & 20 & 30 & 40 & 50 \\
\hline $\begin{array}{l}\text { The share of Russian regions } \\
\text { that have implemented digital } \\
\text { sectoral planning of } \\
\text { agricultural production based } \\
\text { on the digital platform } \\
\text { «Digital Agriculture», \% }\end{array}$ & 0 & 6 & 29 & 59 & 100 & 100 \\
\hline
\end{tabular}

The analysis of target indicators indicates that by 2023 all regions of Russia will introduce digital sectoral planning of agricultural production based on the digital platform «Digital Agriculture», the process of forming resources in Big Data will also be completed, while the growth of labor productivity will be $190-200 \%$.

The issue of training and retraining specialists of agricultural enterprises in the field of the digital economy to work with digital products and technologies will remain problematic.

To assess the results of the implementation of the Digital Agriculture program, the community of leaders of the agricultural industry "Smart Farming Club», within the framework of the plenary session «Practical tools for sustainable development of digitalization in the agro-industrial complex» of the exhibition «Golden Autumn», announced the start of the project «Rating of digital maturity of the agro-industrial complex» ... The project is being implemented with the participation of an independent consultant KPMG and expert support from Sberbank of Russia.

According to the methodology, at the first stage of the rating, it is planned to fill out questionnaires by its participants on the official website of the project. Agricultural enterprises will have to provide not only information about the digital solutions they use, but also about the strategic vision for the development of digitalization in their companies, 
as well as the level of qualifications and knowledge of personnel in the field of high technologies and other data.

The constituent entities of the Russian Federation will present a report on their use of digital technologies, plans and prospects for its further development, measures to create favorable conditions for digital transformation, as well as the competences of specialized departments in the direction of digitalization, work on training young personnel for the agro-industrial complex.

The organizers of the project expect that more than 15 thousand domestic agricultural enterprises and all constituent entities of the Russian Federation will take part in the formation of the rating [4].

As a significant result of the implementation of the «Digital Agriculture» program in 2021, one can call the commissioning of the GIS «Single Window» into industrial operation, where the verified data of the regional authorities of the agro-industrial complex is collected. Based on the data received from the information systems of the Ministry of Agriculture of Russia, other federal executive bodies and control and supervisory bodies that have integration interaction with the GIS «Single Window» and create tools and models for forecasting industry indicators. [4]

At present, in monetary terms, the IT market in agriculture is estimated by experts at more than 360 billion rubles. According to forecasts of the Ministry of Agriculture, it should grow 3-5 times in the next 10-15 years. According to the Ministry of Agriculture of the Russian Federation, the comprehensive digitalization of agricultural production will allow farmers to reduce costs by $23 \%$, reduce crop losses, which, if the means of production are ineffectively used, can be up to $40 \%$ [5].

\section{Discussion}

As a result of ongoing research in the field of digitalization in agriculture, as drivers for the development of digital transformation of the agro-industrial complex in Russia, it is already possible to name a high degree of cooperation between digital service providers for this complex and the almost absence of competition, the presence of large agricultural holdings; government measures to develop the digital economy.

We agree with the opinion of experts who believe that the obstacles to digital transformation of the agricultural sector are: lack of specialized IT specialists; insufficient financial opportunities for large-scale modernization; digital inequality between cities and villages; foreign origin of most information resources [6,7].

However, given the favorable starting conditions and the rapid pace of development of digitalization in Russia, the main "points of application" of digital technologies in the agrifood industry can be identified: increasing crop yields and animal productivity; lower production costs; increasing labor productivity; timely response to climate change; reduction of transaction costs in sales by building a transparent supply chain of products from the field to the consumer; minimization of management risks; reducing the shortage of qualified specialists; informatization of rural producers; simplification of access to borrowed funds; gaining access to digital distribution channels for agricultural producers.

\section{Conclusion}

Thus, at the time of the transformation of business processes in the agro-industrial complex, there was a technological basis of Russian origin, that is, the agricultural digitalization project practically did not depend on the foreign IT sphere. In addition, the domestic agricultural sector at the end of 2019-2021, demonstrates positive results despite the impact 
of sanctions and the pandemic. We believe that in this situation, the transition to smart agriculture technologies allows Russia to become one of the guarantors of global food security.

\section{References}

1. State program for the development of agriculture and regulation of markets for agricultural products, raw materials and food (2005)

2. Decree of the President of the Russian Federation № 204 of May 7, 2018 «On national goals and strategic objectives of the development of the Russian Federation for the period up to 2024» (2018)

3. On the management system for the implementation of the national program "Digital Economy of the Russian Federation": approved. Decree of the Government of the Russian Federation № 234 (2019)

4. The level of digitalization of the agro-industrial complex will be determined in Russia (2021)

5. Order of the Government of the Russian Federation of June 19, 2021 № 1671-r «On approval of the national report on the progress and results of the implementation in 2020 of the State Program for the Development of Agriculture and Regulation of Agricultural Products, Raw Materials and Food Markets, approved by the Resolution of the Government of the Russian Federation №717» (2021)

6. Digital redistribution. Benefits and risks of digitalization of agriculture (2021)

7. V. Zenovina, Smart fields, greenhouses and herds: plans to make agriculture digital (2018)

8. B.A. Voronin, A.N. Mitin, O.A. Pichugin, Agrarian Bulletin of the Urals, 183, 4 (2019) 